\title{
Application of the edu finance model to improve financial literature in creative industry in Sidoarjo district
}

\author{
Eko Purwanto $^{1^{*}}$, Muhadjir Anwar ${ }^{2}$ \\ 1,2Department of Magister Management, \\ Universitas Pembangunan Nasional "Veteran" Jawa Timur, Surabaya, Indonesia \\ *Corresponding author: ekopasca@upnjatim.ac.id
}

\section{Article Info}

Article history:

Received : 4 November 2021

Accepted : 10 November 2021

Published: 1 January 2022

JEL Classification Code: G18, G21, G40

\section{Author's email:}

muhadjira.ma@upnjatim.ac.id

DOI: 10.20885/jsb.vol26.iss1.art4

\begin{abstract}
Purpose: This research aims to observe the development of MSMEs problems that is related to financial knowledge. The importance of educating MSMEs in a systematic, integrated, and sustainable manner regarding financial literacy is expected to be able to build a strong business foundation which is very much needed. Increasing financial literacy is expected to contribute to financial system stability, reduce vulnerabilities in the financial system, and make effective decisions on financial resources.
\end{abstract}

Design/methodology/approach: The data were collected through selfadministered questionnaire. There were 14 items used to edu finance and financial literature. The research design used in this research is quantitative research because it uses data in the form of numbers in descriptive statistical analysis. The results of these calculations will then be compared with the criteria for the level of financial literacy according to Chen and Volpe.

Findings: The results of this study indicate that based on the five variables that use the financial literacy level of MSMEs, women are in the low category. Therefore, an appropriate model is needed to increase financial literacy knowledge in creative industry MSMEs in Sidoarjo District, by prioritizing the importance of planning and evaluation that produces feedback for improving financial literacy.

Research limitation/implications: The data were collected from MSME creative industry sector in Sidoarjo District. It is limited in that it may not have captured the reflections of MSME creative industry sector in Indonesia that maybe differ from the sample used.

Practical implications: The condition of MSMEs in the creative industry sector in Sidoarjo District currently still has limitations with various problems. The limitations experienced include financial skills and financial behavior, as well as limited access to information and technology. Therefore, financial literacy is crucial for MSMEs to improve their business performance. Several studies have been conducted to prove that financial literacy contributes to the improvement of MSME performance.

Originality/value: This research contributes by identifying how respondents need a systematic, integrated, and sustainable education for MSMEs regarding financial literacy to build a strong business foundation.

Keywords: financial literacy, creative industry, edu finance, MSMEs.

\section{Introduction}

COVID-19 pandemic has had an impact on various sectors. At the global economic level, the COVID-19 pandemic has had a very significant impact on the domestic economy where this condition has been seen in East Java's economic growth which grew by 3.04 percent in the first 
quarter, far from the average in the same period which was at 5.55 percent (BPS, 2020). The economic condition in the second quarter of 2020 was getting worse, in which it contracted 5.90 percent when compared to the second quarter of 2019. During this COVID-19 pandemic, almost all businesses experienced a contraction, but there were several business fields that experienced positive growth, namely the information business field, communications, health and social services, as well as agriculture, forestry and fisheries (Devi et al. 2020; Olivia et al. 2020; Lesi, 2020).

This condition is also experienced by micro, small, and medium enterprises (MSMEs) in East Java where the proportion of Micro and Small Enterprises (MSMEs) dominates economic activity with a proportion of around 98.95 percent (BPS, 2020). The role of MSMEs in East Java is quite significant. The results of the calculation of the value added by East Java MSMEs show that in 2016 MSMEs contributed 56.43 percent, increasing to 56.63 percent in 2017 and to 56.43 percent in 2018. However, with the COVID-19 pandemic, MSMEs in East Java is forced to turn its strategy around, some even experiencing a crisis (Soetjipto, 2020; Chevallier, 2020; Ferneini, 2020).

The same condition also occurs in Sidoarjo District. Sidoarjo District is one of the areas that is the center of MSMEs in Indonesia which is in the national spotlight. Because of its success in fostering cooperatives and MSMEs, Sidoarjo has been designated as a MSME city, especially MSMEs in the creative industry sector. The Creative Industry is an industrial sector that originates from the use of individual creativity, skills, and talents to create prosperity and employment opportunities through the creation and utilization of individual creativity, skills, and talents with potential wealth, as well as the creation of job opportunities (Moeuf et al. 2020; Muller et al. 2021; Mountain et al. 2021).

The strength of Sidoarjo District is not only judged by its superior commodities, but also its strategic area. In addition, Sidoarjo District as a satellite city of Surabaya stores various potential resources to be developed. With fairly rapid economic growth, as in 2020 the economic growth will reach 7.08 percent, this condition is also accompanied by the development of business that continue to grow and develop in Sidoarjo District. The great potential of Sidoarjo District will be meaningless if it is not accompanied by its empowerment strategy, especially the MSME actors themselves in seizing and creating competitiveness for their products in the market (Ali et al. 2020; Iborra et al. 2020; Saunila, 2020).

In its development, MSMEs in Sidoarjo District are still experiencing problems related to financial knowledge. Nowadays, financial literacy in MSME actors is a concern of the government and financial institutions in Indonesia. Based on data from the Financial Services Authority, the financial literacy index in Indonesia is only $29.66 \%$. The condition of the lack of financial literacy skills is also experienced by MSME actors in Sidoarjo District. The quality of MSME actors is still low, and their lack of financial knowledge can be seen in their inability in terms of business management, especially bookkeeping regulations, having legal entities that lack knowledge of technology, as well as lack of knowledge about access to capital and MSME funding. Therefore, efforts that must be increased in advancing MSMEs today is by optimizing financial literacy for MSME actors (Panos \& Wilson, 2020; Engels et al. 2020; Dewi et al. 2020).

The efforts can be carried out through improving the business climate and providing assistance that directly supports the ability of MSMEs to compete in the market. The difficulty in accessing capital is due to the low financial literacy of MSE managers. Therefore, financial literacy is crucial for MSMEs to improve their business performance. Several studies have been conducted to prove that financial literacy contributes to the improvement of MSME performance (Kulathunga et al., 2020; Herawati et al., 2020).

The condition of MSMEs in the creative industry sector in Sidoarjo District currently still has limitations with various problems. Basically, in general, there are limited human resources from MSME actors themselves. The limitations include capital, lack of financial knowledge, financial skills, low financial attitude and financial behavior, limited access to information and technology, and the narrow scope of the market which is still a limiting factor for MSMEs (Yuneline \& Suryana, 2020; Grable et al. 2020; Kostini \& Raharja, 2020).

Systematic, integrated, and sustainable education for MSMEs regarding financial literacy is required to build a strong business foundation. Improved financial literacy is expected to contribute to financial system stability, reduce vulnerabilities in the financial system, and make effective 
decisions on financial resources. The ability of financial management are in terms of funding about sources and how to obtain it, as well as making simple financial reports consisting of balance sheets, income statements and changes in capital increased after the training (Jindrichovska, 2013; Engels et al. 2020; Dewi et al. 2020). Financial management training is an effective way to help improve financial literacy for MSME actors (Asuquo, et al. 2014; Grable et al. 2020; Osipov et al. 2018). Training can provide real change, facilitate and enable companies to grow, expand and develop capabilities, and even able to increase profitability, especially in the field of financial management (Taylor, 2013; Toosi et al. 2020; Ford et al. 2020).

Based on this background, this research was conducted in an effort to improve financial literacy skills for creative sector MSME actors in Sidoarjo District by exploring problems that arise in financial management, namely the needs of analysis in understanding financial literacy and effective financial management training models to educate creative sector MSME actors. It is specifically carried out in Sidoarjo District as an effort to improve financial literacy skills in a systematic, comprehensive and sustainable manner. From the background described above, the researcher wants to analyze the implementation of financial management that has been carried out by MSME actors and design an edu-finance management model to improve financial literacy in creative sector MSME actors in Sidoarjo District.

\section{Literature Review}

\section{Financial Literacy}

Literacy according to the Financial Services Authority (2013) is defined as the ability to understand. In the financial context, financial literacy is the ability to manage funds owned so that they can develop and live more prosperously in the future. Kebede \& Kuar (2015; Engels et al. 2020) also revealed that financial literacy is one component of human capital in carrying out financial activities to increase life satisfaction from what has been consumed.

Financial literacy is a determining factor in shaping financial well-being. With good financial knowledge, effective financial decisions can be made so that the use of funds and investment choices becomes more appropriate (Lusardi et al. 2017). The role of financial literacy over time will become more important because technological developments lead to changes in people's lifestyles, including in financial management so that financial literacy will be more complex and require special skills in its management (Panos \& Wilson, 2020; Engels et al. 2020).

According to Huston (2010; Ionescu, 2020) financial literacy occurs when an individual has a set of skills and abilities that make that person able to utilize existing resources to achieve goals. Meanwhile, the President's Advisory Council on Financial Literacy (2008) revealed the stages in measuring financial literacy which include financial knowledge, financial skills, perceived knowledge, and financial behavior. Hastings \& Mitchell (2020) emphasized that one of the most important things in financial management is patience. Patience is the difference between people who understand financial literacy and those who don't. People who have high financial literacy will think more about the long term than the short term in managing finances.

The implementation of education in order to improve public finances is very necessary because based on a survey conducted by Chen \& Volpe (2014), financial literacy is categorized into 3 groups, namely:

1. $<60 \%$, which means that the individual has low knowledge about finances

2. $60 \%-79 \%$ which means that the individual has moderate knowledge about finance

3. $>80 \%$ which indicates that the individual has high knowledge about finances

\section{Financial Knowledge}

Financial knowledge has a close relationship with financial literacy or financial education. Financial knowledge can be channeled and can be understood well through financial literacy. Several studies have shown that low financial literacy is the result of a lack of financial knowledge (Chen \&Volpe 2011; Cai et al., 2020). Some literatures find a positive relationship between financial knowledge 
and financial behavior. Increased financial knowledge is in line with more positive and more responsible financial decisions (Grable et al. 2020; Lind et al. 2020).

Financial knowledge is important, not only for individual interests. Financial knowledge is not only able to make us use finances wisely, but also can provide benefits to the economy. Financial knowledge has the power to change the world. Lack of knowledge of financial management principles and financial matters can cause individual or family financial conditions to become disorganized. To have financial knowledge, it is necessary to develop skills that are known about finance such as recording money in and money out. Financial expertise is a technique for making financial management decisions.

Financial knowledge refers to the knowledge possessed and specifically refers to financial concepts and financial products (Husser, 2015; Cai et al. 2020). Financial knowledge can be identified in two perspectives, namely objective financial knowledge and subjective financial knowledge. Objective financial knowledge by using knowledge-based questions, while subjective financial knowledge by asking people to rate their level of financial knowledge (Mountain et al. 2021)

\section{Financial Skills}

Building financial literacy requires skills in managing finances (Donng \& Doukas, 2020). Skill is the ability to use ideas and creativity in doing, changing, or making something more meaningful so as to produce a value from the work. Skill has 3 indicators, namely, Technical skills, Management skills, Entrepreneur skills (Sariwulan et al. 2020). Sharpening skills in financial management will require expanding financial literacy, so that some researchers correlate financial skills and financial literacy (Dewi et al. 220).

Willis (2008; Donng \& Doukas, 2020) stated that knowledge in the context of financial literacy includes knowledge, education, and information about finance and its sources, banking, deposits, credit, insurance, and taxes. Financial knowledge possessed by a person develops into financial skills. Financial skills are defined as the ability to apply their financial knowledge in everyday life. Financial skills allow a person to be able to make rational and effective decisions related to finances and economic resources. Therefore, financial skills are very important in making financial decisions for the welfare of the business in the long term.

Skill, creativity and innovation are related. With good skills, it will foster creativity, and with creativity, innovation will be created. Therefore, financial skills are needed in this digital era, as financial technology demands creativity and innovation that will be realized if you have financial skills (Saravanakumar, 2020).

\section{Financial Behavior}

Many studies show that financial literacy has a positive correlation with financial behavior. A person's financial behavior can be demonstrated by how people treat, manage, and use the financial resources available to them. The emergence of financial behavior is the impact of a person's desire to meet the needs of his life in accordance with the behavior of the income earned. A person's financial behavior can be seen from four things, namely consumption, cash flow management, cash flow savings, and credit management.

Nidar \& Bestari (2012) stated that financial behavior is behavior related to financial practices or applications. Financial behavior relates to how a person can manage and use the financial resources available to him (Dwiastanti, 2015; Ionescu, 2020). Meanwhile, according to Rochlin \& Simon (2011), financial behavior is a discipline in which the interaction of various disciplines is embedded and continuously integrated so that the discussion is not isolated.

Discussions related to financial behavior in some of the latest literature show the role of financial behavior is increasingly widespread. Ionescu (2020) stated that financial behavior is one of the main factors to shape environmental health and sustainable energy. Kostini \& Raharja (2020) summarized 9 indicators to measure financial behavior, including good financial management, recording every financial transaction, availability of financial records that do not comply with financial accounting standards, perception of the use of business funds for personal purposes, use of business 
funds for the purchase of company assets, payment due to creditors, separating personal expenses from company operations, periodic planning for company operations, spontaneous purchases.

\section{Financial Attitude}

Hayhoe et al. (2012) stated that there is a relationship between financial attitude and the level of financial problems. Thus it can be said that a person's financial attitude also affects the way a person regulates his financial behavior. Meanwhile, according to Robbins \& Judge (2008), the attitude is evaluative statement both the favorable and that is not fun to objects, people, and events.

Financial attitude is a form of financial allocation made by a person which refers to the benefits, needs, and resources owned (Magli et al. 2020). Financial attitude is influenced by several factors including social engagement and environment (Coskun \& Dalziel, 2020). Financial attitude teaches that financial management must be carefully planned and must have priority needs from primary to tertiary (Sabri et al. 2020).

Financial attitude has a positive impact on the development of financial literacy (Dewi et al. 2020). A number of literatures emphasize that financial literacy can be formed and developed by increasing financial knowledge, financial behavior, and financial attitude (Kadoya \& Khan, 2020; Dewi et al. 2020). Castro-Gonzales et al. (2020) added that financial attitude, especially attitude to money, can improve financial well-being.

\section{Financial Performance}

According to Mulyadi (2010) financial performance can be understood as the achievement achieved by the company in a certain period that reflects the level of health of the company. According to Munawir (2010) the company's financial performance is one of the basic assessments of the company's financial condition based on an analysis of financial ratios.

Interested parties really need the results of financial performance measurements to be able to see the condition of the company and the level of success of the company in carrying out operational activities. The company's financial performance is categorized as good if the company's financial ratios are equal to or above the standard financial ratios. In addition, the notion of financial performance according to Kulathunga et al. (2020) is that financial performance is an analysis carried out to see the extent to which a company has implemented by using financial implementation rules properly and correctly.

From the definition that has been put forward, it can be concluded that financial performance is an achievement achieved by a company in a certain period which reflects the soundness of a company that has implemented or used financial implementation rules properly and correctly (Zahroh et al. 2020). One of the efforts to establish good financial performance is to improve financial literacy (Ishtiaq et al. 2020). Financial literacy, financial knowledge, skills, and behavior are important components to optimize financial performance (Kulathunga et al. 2020).

\section{Research Framework}

The design of the training model to improve financial literacy for MSME actors is depicted in Figure 1.

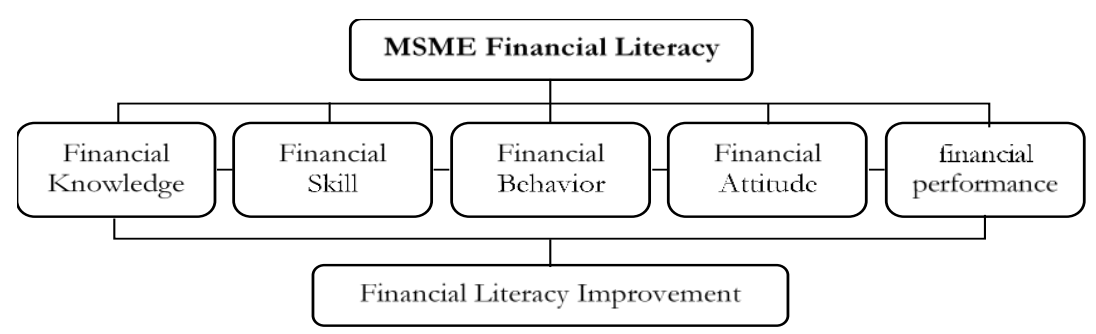

Figure 1. Model to Improve Financial Literacy for MSME

Based on the conceptual framework in Figure 1, it can be known that the assessment of financial literacy in the creative industry sector MSMES economic actors in Sidoarjo District based on financial knowledge, financial skills, financial behavior, financial attitude, and financial performance is calculated 
through the criteria for assessing the level of financial literacy (Zahroh et al. 2020; Magli et al. 2020; Toosi et al. 2020). Therefore, after the results of the assessment are obtained for the criteria for the level of financial literacy, it is known that the level of financial literacy of the creative industry sector MSMES economic actors in Sidoarjo District is low if it is said to be $<60 \%$, classified as moderate if the average is between $60 \%-79 \%$, and classified as high if it is said to be $>80 \%$ based on financial variables. knowledge, financial skills, financial behavior, financial attitude and financial performance.

\section{Methods}

The sample in this study used 68 respondents of MSMEs economic actors in the creative industry sector in Sidoarjo District. The sampling technique in this study was adjusted to the population because the creative industry sector MSME actors in Sidoarjo District were few, namely only 68 MSME actors. According to Sugiyono (2017) simple random sampling is a sampling method that collects sample members from the population and is carried out randomly without regard to the strata that exist in the population .

The research design used in this research is quantitative research because it uses data in the form of numbers in descriptive statistical analysis. The results of these calculations will then be compared with the criteria for the level of financial literacy according to Chen and Volpe (quoted in Galang et al, 2017:36). The criteria for the level of financial literacy are divided into:

a. High, if the literacy rate exceeds $80 \%$

b. Medium, if the literacy rate is between $60 \%$ to $79 \%$

c. Low, if the literacy rate is less than $60 \%$

\section{Results and Discussion}

\section{Research Results}

This study aims to determine the knowledge of financial literacy in the creative industry sector of MSMEs economic actors in Sidoarjo District from 68 respondents with 14 indicator questions based on financial knowledge, financial skills, financial behavior, financial attitude, and financial performance. The respondent's data is then processed and the results of the explanation can be seen below:

Table 1. Financial Literacy level

\begin{tabular}{|c|c|c|c|c|}
\hline \multirow[b]{2}{*}{ Aspect } & \multirow[b]{2}{*}{ Question } & \multicolumn{3}{|c|}{ Financial Literacy Level } \\
\hline & & $\begin{array}{c}\text { Low } \\
(<60 \%)\end{array}$ & $\begin{array}{c}\text { Medium } \\
(60 \%<79 \%)\end{array}$ & $\begin{array}{l}\text { High } \\
(>80 \%)\end{array}$ \\
\hline \multirow{6}{*}{ Financial Knowledge } & 1. Financial statement knowledge & & $72 \%$ & \\
\hline & 2. Knowledge of expenditure and income & & $70 \%$ & \\
\hline & 3. Personal budget knowledge & & $76 \%$ & \\
\hline & 4. Investment knowledge & & $74 \%$ & \\
\hline & Average & & $72 \%$ & \\
\hline & 1. Budget skills & & $69 \%$ & \\
\hline \multirow{2}{*}{ Financial Skills } & 2. Investment skills & $49 \%$ & & \\
\hline & Average & $59 \%$ & & \\
\hline \multirow{5}{*}{ Financial Behavior } & 1. Behavior in financial statements & & $60 \%$ & \\
\hline & 2. Expenditure reports & & $62 \%$ & \\
\hline & 3. Saving behavior & $56 \%$ & & \\
\hline & 4. Tax behavior & $59 \%$ & & \\
\hline & Average & $59 \%$ & & \\
\hline \multirow{3}{*}{ Financial Attitude } & 1. Financial attitude & $58 \%$ & & \\
\hline & 2. Attitude to manage money & $39 \%$ & & \\
\hline & Average & $49 \%$ & & \\
\hline \multirow{3}{*}{ Financial performance } & 1. Financial performance & & $62 \%$ & \\
\hline & 2. How to manage financial performance & & $64 \%$ & \\
\hline & Average & & $63 \%$ & \\
\hline
\end{tabular}


From the results of the data analysis above, the financial knowledge variable in the creative industry sector MSMEs in Sidoarjo District is medium with an average total value of $72 \%$. The second variable, namely financial skills in the creative industry sector MSMES in Sidoarjo District, is low with an average total value of $59 \%$. The third variable, namely financial behavior in the creative industry sector MSMEs in Sidoarjo District is low with an average total value of $59 \%$. The fourth variable, namely financial attitude in the creative industry sector MSMEs in Sidoarjo District is low with an average total value of $49 \%$. The fifth variable, namely the financial performance of the creative industry sector MSMEs in Sidoarjo District is medium with an average total value of $63 \%$. The results can be concluded from the five variables that have a relationship between one variable and another. In this regard, the better the value of financial knowledge, financial skills, financial behavior, financial attitude and financial performance, the higher the value of the level of financial literacy owned by MSMEs in the creative industry sector in Sidoarjo District. From the results of the data above, the financial literacy level of MSMEs in the creative industry sector in Sidoarjo District is at the middle level. Therefore, researchers want to improve the financial literacy of MSMEs in the creative industry sector in Sidoarjo District so that they can be better better at managing their businesses, both from financial knowledge, financial skills, financial behavior, financial attitude, and financial performance.

\section{Discussion}

This study aims to determine the influence of financial knowledge, financial skills, financial behavior, financial attitude and financial performance on financial literacy of the creative industry sector MSMEs in Sidoarjo District. The results of the analysis of financial knowledge variables have an average value of $72 \%$. Chen \& Volpe (2014; Dewi et al. 2020) categorized financial literacy into three groups. This means that from the data, the financial knowledge of the creative industry sector MSME actors in Sidoarjo District is at the middle category level, which indicates that the financial knowledge possessed is quite good because of the factors that cause the lack of knowledge of the creative industry sector MSME actors in Sidoarjo District. Thus, the limited education taken is one of the inhibiting factors. By having good financial knowledge, a person will find it easier to apply financial literacy to run a business owned by MSMEs in the creative industry sector in Sidoarjo District.

Financial skill is a technique for making decisions in one's finances, as preparing a budget, choosing investments, choosing an insurance plan, and using credit are examples of financial skills (Kholilah \& Iramani, 2013; Sariwulan et al. 2020). The results of the analysis of the financial skills variable have an average value of $59 \%$. Chen \& Volpe (2014) categorized financial literacy into three groups. It means that from the data, the financial skills possessed by the creative industry sector of MSME actors in Sidoarjo District are at a low category level, which indicates that the financial skills they have are not good because of factors that cause a lack of financial training or financial ability. It causes the creative industry sector MSME actors in Sidoarjo District to lack financial literacy. They are also experienced with limited financial training such as seminars or socialization of difficult financial management. Consequently, MSME actors in the creative industry sector are not good at saving, and they must be encouraged to take loans so that they get more income, but on the other hand they will be afraid to pay their debts. By having poor financial skills, someone will have difficulty in managing their finances, because to implement good financial literacy, one must have the skills or ability to manage their finances to make it easier to run a business.

The development of financial behavior is spearheaded by the existence of a person's behavior in the process of financial decisions making. Ida \& Dwinta (2010; Dewi et al. 2020) stated that financial behavior is a person's ability to organize, plan, budget, examine, manage, control, search, and store daily financial funds (Kholilah \& Iramani, 2013). Financial knowledge is a person's mastery of various things about the financial world (Kholilah \& Iramani, 2013; Yuneline \& Sryana, 2020). The results of data analysis on financial behavior variables have an average value of $59 \%$. Chen \& Volpe (2014; Toosi et al. 2020) categorized financial literacy into three groups. This means that from the data, the financial behavior of the creative industry sector MSME actors in Sidoarjo District is at the low category level, which indicates that the financial knowledge possessed is not good because of the factors that cause the lack of knowledge of the creative industry sector MSME 
actors in Sidoarjo District to manage basic finances such as saving, paying taxes, and investments. Thus, the limitations in financial behavior that is owned taken is one of the inhibiting factors. By having good financial behavior, a person will find it easier to apply financial literacy to run a business owned by MSMEs in the creative industry sector in Sidoarjo District.

Attitude refers to how a person feels about personal financial matters, which is measured by the response to a statement or opinion (Magli et al., 2020; Osipov et al. 2018). Pankow (2003) defined financial attitudes as a state of mind, opinion, and judgment about finances. The financial attitudes variable has an average value of $49 \%$. Chen \& Volpe (2014) categorized financial literacy into three groups. it means that from the data the financial attitudes of the creative industry sector MSME actors in Sidoarjo District are at a low category level. It indicates that the financial attitudes they have are not very good because of the factors that lead to a lack of financial attitudes and financial responsibility owned by the creative industry sector of MSME actors in Indonesia. Sidoarjo District. With a lack of financial responsibility, they do not dare to take risks for fear of personal financial problems. And most of the MSME actors in the creative industry sector in Sidoarjo District have a very old-fashioned view of money, such as the assumption that money is better kept alone without saving it in a bank or for investment. In fact, having a good financial attitude will make it easier for someone to apply financial literacy to run a business owned by MSMEs in the creative industry sector in Sidoarjo District.

Financial performance is the operational effectiveness of an organization and its employees based on predetermined targets, standards, and criteria (Mulyadi, 200). However, MSMEs tend to have resilience or stable performance against changes in the business and economic climate, as this is evidenced in research conducted by Aribawa (2016; Ionescu, 2020; Kostini \& Raharja, 2020) that with good financial literacy, it is expected that MSMEs will be able to make appropriate management and financial decisions to improve business performance and sustainability. The results of the data in Table 1 show that financial performance variables have an average value of 63\%. Chen \&Volpe (2014; Dewi et al. 2020) categorized financial literacy into three groups. It can be interpreted from the data that the financial performance of the creative industry sector MSME actors in Sidoarjo District is at the middle category level, which shows that the financial performance is quite good because of the factors that cause the lack of success in managing MSME finances, especially the limited capital owned, less stable conditions of liquidity, and profitability in MSMEs. Therefore, that with these limitations, it becomes one of the inhibiting factors in its financial performance. By having good financial performance, a person will find it easier to apply financial literacy to run a business owned by MSME actors in the creative industry sector in Sidoarjo District, so that the MSME financial situation is always stable.

Based on the results of the research above, the financial education model that can be used by MSMEs in the creative industry sector in Sidoarjo District in the future.

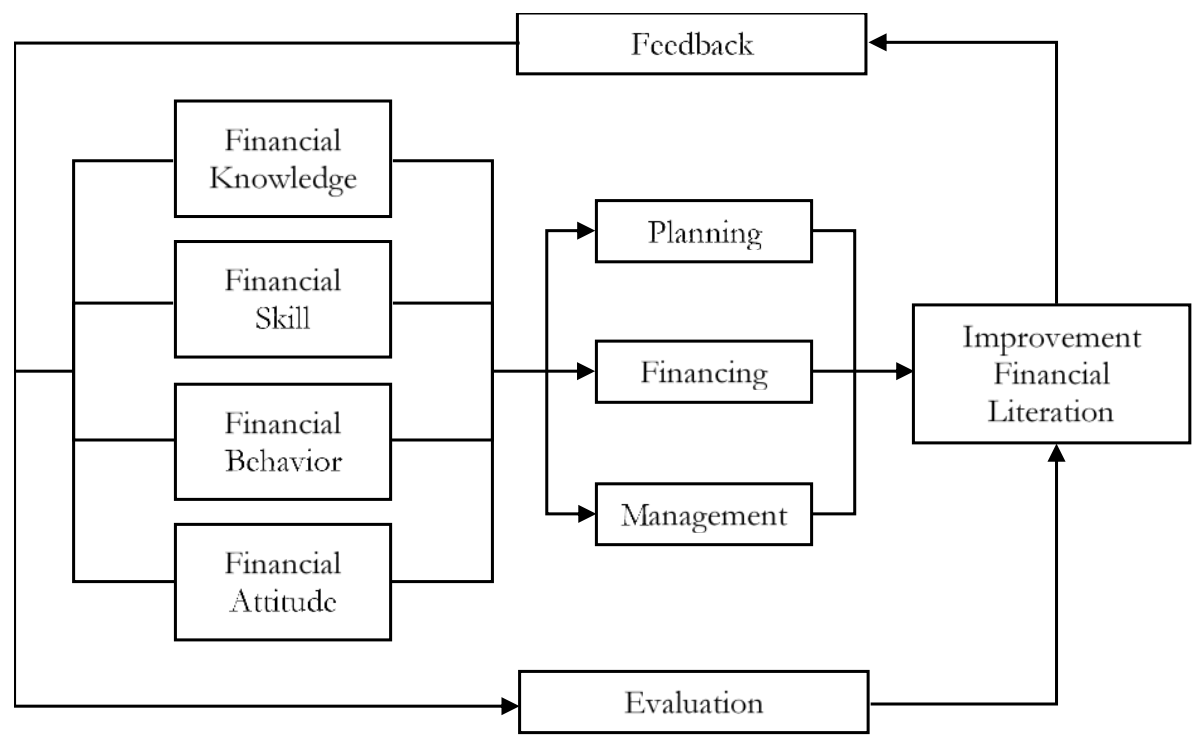

Figure 2. Edu Finance Model for MSMEs 
Planning function of funds is the activity of planning the need for funds. In this function, the concern is how the financial management or financial manager can plan the funding needs, what activities are prioritized in the company and what are the sources of funding, who is authorized to make decisions in funding, why there must be funding planning, where sources of funding must be obtained, when funding planning must be carried out, and how funds are needed by the company. There are several things that need to be applied to MSMEs:

a. MSME business managers in the creative industry sector in Sidoarjo District need to prepare a clear plan in writing about the capital needed and the use of funds to be made (money out).

b. MSME managers in the creative industry sector in Sidoarjo District need to calculate the profit and loss before investing in renting/buying fixed assets such as renting/buying a car or land for this business

Financing is an activity in an effort to obtain the necessary funds at low costs and light conditions. In obtaining funds, it must refer to considerations of efficiency and effectiveness where business managers need to carefully consider the nature and costs of each source of funds to be selected, because each source of funds has different consequences. Therefore, in seeking and obtaining funds to run a business, MSME business managers in the creative industry sector in Sidoarjo District need to always try to get funds with the smallest possible capital costs and as easy as possible requirements so that the profits obtained can later be maximized.

In this case, there are several things that should be considered when managing funds effectively and efficiently so that the allocation of these funds actually reaches the desired target, so that the company's goals are achieved. Existing funds must be allocated or invested in business that will bring maximum profits. In this regard, the MSME business managers in the creative industry sector in Sidoarjo District must always control their business trips so as to achieve the desired goals, where managers need to:

a. Record every sales transaction occurs. From the sales records, an income statement can be prepared which can provide information for managers or business owners in controlling their business. Apart from that, disciplined financial records will make it easier for entrepreneurs.

b. Get additional capital from the bank. For this reason, disciplined financial bookkeeping is needed so that it can be more trusted by the bank that will provide business loan funds.

c. Counting and recording the amount of seed stock so that the business is really well controlled and financial reports, especially the balance sheet, can be prepared. From the balance sheet, it can be seen how the actual financial condition of the business is.

Feedback needs to be done to determine the extent of the allocation of the budget in accordance with the plan. If it is appropriate, it is necessary to make a new plan in order to achieve the business development objectives, but if it is not appropriate, then it is necessary to find the root cause of the non-conformity and include it in the action plan for the next period of time, so that the financial management can continue to be carried out on an ongoing basis.

This is explained by Ali et al. (2020; Iborra et al. 2020; Saunila, 2020) that financial statements play a very important role in businesses of any scale, in addition to being a reference for business owners in making decisions, also especially to obtain an overview of the company's financial performance, profit or loss. Likewise on the micro, small and medium scale, good and orderly records will help a business actor to know what transactions his business has made during a certain period. Also conveyed by Engels et al. (2020; Dewi et al. 2020), the desire or intention of the informant to develop a business and to facilitate the payroll has motivated the informant to always do the form of financial records.

\section{Conclusion}

From the results of the data analysis above, the financial knowledge variable in the creative industry sector MSMEs in Sidoarjo District is medium with an average total value of $72 \%$. The second variable, namely financial skills in the creative industry sector MSMEs in Sidoarjo District, is low with an average total value of $59 \%$. The third variable, namely financial behavior in the creative 
industry sector MSMEs in Sidoarjo District is low with an average total value of $59 \%$. The fourth variable, namely financial attitude in the creative industry sector MSMEs in Sidoarjo District is low with an average total value of $49 \%$. The fifth variable, namely the financial performance of the creative industry sector MSMEs in Sidoarjo District is medium with an average total value of 63\%. Therefore, it is necessary to implement the Edu Finance Model, which consists of:

a. Fund Planning: MSME business managers in the creative industry sector in Sidoarjo District need to develop a clear plan in writing about the capital needed and the use of funds to be made (money out).

b. Expenditure: Record every sales transaction occurs. From the sales records, an income statement can be prepared which can provide information for managers or business owners in controlling their business. Apart from that, disciplined financial records will make it easier for entrepreneurs.

c. MSME managers in the creative industry sector in Sidoarjo District need to take into account the pros and cons before allocating investments to rent/buy fixed assets such as renting/buying a car or land for this business.

d. Feedback needs to be done to find out how far the budget allocation is as planned. If it is appropriate, it is necessary to make a new plan in order to achieve the business development objectives but if it is not appropriate, then it is necessary to find the root cause of the nonconformity and include it in the action plan in the next period of time so that financial management can continue to be carried out on an ongoing basis.

\section{Reference}

Ali, H., Hao, Y., \& Aijuan, C. (2020). Dynamic Capabilities, Environmental Dynamism and Small and Medium Enterprises' Internationalization Level. The Journal of Asian Finance, Economics, and Business, 7(9), 527-536.

Aribawa, D. (2016). E-commerce strategic business environment analysis in Indonesia. International Journal of Economics and Financial Issues, 6(6S), 130-134.

Asuquo, M., Coward, I., \& Yang, Z. (2014). Modeling selection of third party ship management services. Case Studies on Transport Policy, 2(1), 28-35.

BPS (Central Bureau of Statistics). (2020). Economic Growth in East Java. Report

Cai, X., Hu, Z., \& Chen, J. (2020). A many-objective optimization recommendation algorithm based on knowledge mining. Information Sciences, 537, 148-161.

Castro-González, S., Fernández-López, S., Rey-Ares, L., \& Rodeiro-Pazos, D. (2020). The influence of attitude to money on individuals' financial well-being. Social Indicators Research, 148(3), 747-764.

Chen, H. \& Volpe, R. (2014). An Analysis of Personal Financial Literacy Among College Students, Financial Services Review, 7(2), 107-128.

Chevallier, J. (2020). COVID-19 pandemic and financial contagion. Journal of Risk and Financial Management, 13(12), 309.

Çoşkun, A., \& Dalziel, N. (2020). Mediation effect of financial attitude on financial knowledge and financial behavior: The case of university students. International Journal of Research in Business and Social Science (2147-4478), 9(2), 01-08.

Dewi, V., Febrian, E., Effendi, N., \& Anwar, M. (2020). Financial Literacy among the Millennial Generation: Relationships between Knowledge, Skills, Attitude, and Behavior. Australasian Accounting, Business and Finance Journal, 14(4), 24-37.

Devi, S., Warasniasih, N. M. S., Masdiantini, P. R., \& Musmini, L. S. (2020). The impact of COVID19 pandemic on the financial performance of firms on the Indonesia stock exchange. Journal of Economics, Business, \& Accountancy Ventura, 23(2), 226-242. 
Dong, F., \& Doukas, J. A. (2020). When fund management skill is more valuable?. European Financial Management, 26(2), 455-502.

Dwiastanti, A. (2015). Financial Literacy as the Foundation for Individual Financial Behavior. Journal of Education and Practice, 6(33), 99-105.

Engels, C., Kumar, K., \& Philip, D. (2020). Financial literacy and fraud detection. The European Journal of Finance, 26(4-5), 420-442.

Ferneini, E. M. (2020). The financial impact of COVID-19 on our practice. Journal of Oral and Maxillofacial Surgery, 78(7), 1047.

Financial Services Authority. (2013). NUMBER: 1/POJK.07/2013. Concerning Consumer Protection in The Financial Services Sector.

Ford, M. R., Ellis, É. M., Goetz, J., Archuleta, K. L., Gale, J. E., Grossman, B., ... \& Gonyea, J. (2020). Depression and financial distress in a clinical population: The value of interdisciplinary services and training. Contemporary family therapy, 42(1), 5-14.

Grable, J. E., Archuleta, K. L., Ford, M. R., Kruger, M., Gale, J., \& Goetz, J. (2020). The moderating effect of generalized anxiety and financial knowledge on financial management behavior. Contemporary Family Therapy, 42(1), 15-24.

Hastings, J., \& Mitchell, O. S. (2020). How financial literacy and impatience shape retirement wealth and investment behaviors. Journal of Pension Economics \& Finance, 19(1), 1-20.

Hayhoe, C. R., Cho, S. H., DeVaney, S. A., Worthy, S. L., Kim, J., \& Gorham, E. (2012). How do distrust and anxiety affect saving behavior?. Family and Consumer Sciences Research Journal, 41(1), 69-85.

Herawati, N. T., Candiasa, I. M., Yadnyana, I. K., \& Suharsono, N. (2020). The influence of gender and financial literacy on accounting implementation in small and micro business (SMES). International Journal of Innovation, Creativity and Change, 12(4), 36-50.

Hüsser, A. (2015). The role of investors' objective financial knowledge on the assessment of risk disclosures in mutual fund advertisements. Journal of Financial Services Marketing, 20(1), 5-22.

Huston, S. J. (2010). Measuring financial literacy. Journal of consumer affairs, 44(2), 296-316.

Iborra, M., Safón, V., \& Dolz, C. (2020). What explains the resilience of SMEs? Ambidexterity capability and strategic consistency. Long Range Planning, 53(6), 101947.

Ida, I. D. A., \& Dwinta, C. Y. (2010). Pengaruh Locus Of Control, financial knowledge, income terhadap financial management behavior. Jurnal Bisnis dan Akuntansi, 12(3), 131-144.

Ionescu, L. (2020). The economics of the carbon tax: environmental performance, sustainable energy, and green financial behavior. Geopolitics, History, and International Relations, 12(1), 101 107.

Ishtiaq, M., Songling, Y., Hassan, A., \& Hayat, A. (2020). The role of financial literacy in resource acquisition and financial performance; moderating role of government support. International Journal of Business and Economics Research, 9(1), 29.

Jindrichovska, I. (2013). Financial management in SMEs.European Research Studies.16(4), 79-95.

Kadoya, Y., \& Khan, M. S. R. (2020). Financial Literacy in Japan: New Evidence Using Financial Knowledge, Behavior, and Attitude. Sustainability, 12(9), 3683.

Kebede, M., \& Kuar, J. (2015). Financial literacy and management of personal finance: a review of recent literatures. Research Journal of Finance and Accounting, 6(13), 92-106.

Kholilah, N., \& Iramani, R. (2013). Studi financial management behavior pada masyarakat surabaya. Journal of Business and Banking, 3(1), 69-80. 
Kostini, N., \& Raharja, S. U. J. (2020). Analysis of Financial Behavior of SMes in the Creative industries in Bandung City, indonesia. Review of Integrative Business and Economics Research, 9(1), 131-139.

Kulathunga, K. M. M. C. B., Ye, J., Sharma, S., \& Weerathunga, P. R. (2020). How does technological and financial literacy influence SME performance: Mediating role of ERM practices. Information, 11(6), 297.

Lesi, H. (2020). The Influence of Information Technology Covid-19 Plague Against Financial Statements and Business Practices. Ilomata International Journal of Tax and Accounting, 1(3), 122-131.

Lind, T., Ahmed, A., Skagerlund, K., Strömbäck, C., Västfjäll, D., \& Tinghög, G. (2020). Competence, confidence, and gender: The role of objective and subjective financial knowledge in Household finance. Journal of Family and Economic Issues, 41(4), 626-638.

Lusardi, A., Samek, A., Kapteyn, A., Glinert, L., Hung, A., \& Heinberg, A. (2017). Visual tools and narratives: New ways to improve financial literacy. Journal of Pension Economics \& Finance, 16(3), 297-323.

Moeuf, A., Lamouri, S., Pellerin, R., Tamayo-Giraldo, S., Tobon-Valencia, E., \& Eburdy, R. (2020). Identification of critical success factors, risks and opportunities of Industry 4.0 in SMEs. International Journal of Production Research, 58(5), 1384-1400.

Mountain, T. P., Kim, N., Serido, J., \& Shim, S. (2021). Does type of financial learning matter for young adults' objective financial knowledge and financial behaviors? A longitudinal and mediation analysis. Journal of Family and Economic Issues, 42(1), 113-132.

Müller, J. M., Buliga, O., \& Voigt, K. I. (2021). The role of absorptive capacity and innovation strategy in the design of industry 4.0 business Models-A comparison between SMEs and large enterprises. European Management Journal, 39(3), 333-343.

Mulyadi. (2010). Sistem Akuntansi, Edisi ke-3, Cetakan ke-5. Penerbit Salemba. Empat, Jakarta

Munawir, S. (2010). Analisis laporan Kenangan Edisi ke-4. Cetakan Ke-15. Yogyakarta: Liberty.

Nidar, S. R., \& Bestari, S. (2012). Personal financial literacy among university students (case study at Padjadjaran University students, Bandung, Indonesia). World Journal of Social Sciences, 2(4), $162-171$

Olivia, S., Gibson, J., \& Nasrudin, R. A. (2020). Indonesia in the Time of Covid-19. Bulletin of Indonesian Economic Studies, 56(2), 143-174.

Osipov, P., Ziyatdinova, J., \& Girfanova, E. (2018, September). Factors and barriers in training financial management professionals. In International Conference on Interactive Collaborative Learning (pp. 167-175). Springer, Cham.

Panos, G. A., \& Wilson, J. O. (2020). Financial literacy and responsible finance in the FinTech era: capabilities and challenges. The European Journal of Finance, 26(4-5), 297-301.

Pankow, Debra (2003). Financial,V alues,Attitudes and Goals. North Dakota StateUniversity Fargo, North Dakota

President's Advisory Council on Financial Literacy. (2008). Annual Report. The Department of Treasury.

Rochlin, J. M., \& Simon, H. K. (2011). Does fellowship pay: what is the long-term financial impact of subspecialty training in pediatrics?. Pediatrics, 127(2), 254-260.

Sabri, M., Wijekoon, R., \& Rahim, H. (2020). The influence of money attitude, financial practices, self-efficacy and emotion coping on employees' financial well-being. Management Science Letters, 10(4), 889-900. 
Sariwulan, T., Suparno, S., Disman, D., Ahman, E., \& Suwatno, S. (2020). Entrepreneurial performance: The role of literacy and skills. The Journal of Asian Finance, Economics, and Business, 7(11), 269-280

Saravanakumar, A. R. (2020). Life skill education for creative and productive citizens. Journal of Critical Reviews, 7(9), 554-558.

Saunila, M. (2020). Innovation capability in SMEs: A systematic review of the literature. Journal of Innovation \& Knowledge, 5(4), 260-265.

Soetjipto, N. (2020). Ketahanan UMKM Jawa Timur melintasi pandemi covid-19. Yogyakarta: K-Media.

Sugiyono. (2017). Methods Research Quantitative Qualitative and R \& D. Bandung: Alphabeta.

Taylor, J. B. (2013). Getting off track: How government actions and interventions caused, prolonged, and worsened the financial crisis. Hoover Press.

Toosi, N. R., Voegeli, E. N., Antolin, A., Babbitt, L. G., \& Brown, D. K. (2020). Do financial literacy training and clarifying pay calculations reduce abuse at work?. Journal of Social Issues, 76(3), 681-720.

Robbins, Stephen P.\&Judge, T. (2007). Financial attitude (12th Edition). Salemba Four: Jakarta.

Willis, L. E. (2008). Against financial-literacy education. Iowa L. Rev., 94, 197.

Yuneline, M. H., \& Suryana, U. (2020). Financial Literacy and its Impact on Funding Source's Decision-Making. International Journal of Applied Economics, Finance and Accounting, 6(1), 1-10.

Zahroh, Z. A., Suhadak, S., Saifi, M., \& Firdausi, N. (2020). The Effect of Company Characteristics and Cooperate Social Responsibility on Company Financial Performance. JPAS Journal of Public Administration Studies), 5(1), 15-18. 